\title{
Puccinia psidii infecting cultivated Eucalyptus and native Myrtaceae in Uruguay
}

\author{
Carlos A. Pérez ${ }^{1,2}$, Michael J. Wingfield ${ }^{3}$, Nora A. Altier ${ }^{4}$, Sofía Simeto ${ }^{4}$ and Robert A. \\ Blanchette $^{1}$
}

(1) Department of Plant Pathology, University of Minnesota, 495 Borlaug Hall, 1991 Upper Buford Circle, St. Paul, MN 55108, USA.

(2) Departamento de Protección Vegetal, EEMAC, Universidad de la República, Ruta 3, km 363, Paysandú, Uruguay.

(3) Forestry and Agricultural Biotechnology Institute (FABI), University of Pretoria, Pretoria, South Africa.

(4) Instituto Nacional de Investigación Agropecuaria (INIA), Ruta 48, km 10, Canelones, Uruguay.

\section{Carlos A. Pérez}

Email: caperez@fagro.edu.uy

\begin{abstract}
Eucalyptus or guava rust caused by Puccinia psidii is a serious disease of Eucalyptus and other Myrtaceae. In Uruguay, it has been previously found on Eucalyptus globulus and Psidium brasiliensis. Almost nothing is known regarding the occurrence of this pathogen on other Eucalyptus species or native Myrtaceae in that country. In this study, we determined the presence of P. psidii on Eucalyptus species and native Myrtaceae trees in Uruguay and evaluated the pathogenicity of specimens from native myrtaceous hosts on E. globulus and E. grandis. Phylogenetic analyses based on the internal transcribed spacer (ITS) region of the nuclear ribosomal DNA operon were used to confirm pathogen identity. Comparisons of ITS sequences confirmed the identity of P. psidii on Eucalyptus globulus, E. grandis, Myrcianthes pungens, and Myrrhinium atropurpureum var. octandrum. This is the first report of $P$. psidii on M. atropurpureum var. octandrum. Pathogenicity tests showed that isolates from native Myrtaceae could infect both Eucalyptus species tested, indicating a strong biological relationship between both introduced and native Myrtaceae. This study supplies relevant field data, morphological information, molecular phylogenetic analyses and infection studies that contribute to a better understanding of an important and little studied pathogen.
\end{abstract}

\section{Introduction}

The guava or Eucalyptus rust, Puccinia psidii Winter, was first found in 1884 on Psidium guajava L. (syn. Psidium pomiferum L.) in Brazil (Winter 1884) and was discovered on non-native eucalypts (Corymbia citriodora (Hook) Hill \& Johnson syn: Eucalyptus citriodora Hook), in the same country in 1944 (Joffily 1944). This was the first record of the rust having undergone a host jump from a native to a non-native tree (De Castro et al. 1983). Subsequent to its first discovery, P. psidii has been recorded on many species in the Myrtaceae from the Americas, Hawaii and more recently in Japan (Acuña and Garran 2004; Alfenas et al. 2004; Dianese et al. 1984; Ferreira 1981, 1983; Kawanishi et al. 2009; MacLachlan 1938; Marlatt and Kimbrough 1979; Rayachhetry et al. 2001; Uchida et al. 2006; Walker 1983). 
Puccinia psidii is considered a devastating pathogen of Eucalyptus in Brazil, causing severe damage on Eucalyptus trees younger than 2 years old (Alfenas et al. 2004; Coutinho et al. 1998). This rust is unique because of its exceedingly wide host range, for which Simpson et al. (2006) cite 71 host species. Its wide host range and aggressiveness on certain hosts make this rust a major threat to Eucalyptus and other Myrtaceae throughout the world (Coutinho et al. 1998; Glen et al. 2007; Grgurinovic et al. 2006; Langrell et al. 2008).

In Uruguay, $P$. psidii was first found on Psidium brasiliensis L. (Koch de Brotos et al. 1981). The rust has been more recently reported on plantation-grown Eucalyptus globulus Labill. subsp. globulus (hereafter E. globulus) where it caused severe damage to 1-year-old trees (Telechea et al. 2003). This was the first record of P. psidii on E. globulus and it raised concerns that the rust could threaten the important Eucalyptus forestry industry in Uruguay.

Little is known of the occurrence of P. psidii on cultivated Eucalyptus spp. or native Myrtaceae trees in Uruguay. For this reason, information on its host range on these taxa represents a fundamental requirement to develop an effective disease management program. Therefore, the aim of this study was to determine the occurrence of $P$. psidii on Eucalyptus species and native Myrtaceae trees in Uruguay. In addition, the pathogenicity of isolates obtained from native myrtaceous hosts on the two most important Eucalyptus spp. planted in Uruguay, E. globulus and E. grandis (Hill) Maiden, was evaluated.

\section{Materials and methods}

\section{Rust collections}

During 2005 to 2007, Eucalyptus plantations and natural forest were examined throughout Uruguay for rust pustules. Surveys included sites randomly selected in the provinces of Canelones, Durazno, Florida, Lavalleja, Maldonado, Paysandú, Río Negro, Rivera, Tacuarembó and Treinta y Tres. Each sampling site represented a location where Eucalyptus plantations and native trees were close to each other $(<500 \mathrm{~m})$. Each site was visited at least twice during this study and each visit was conducted during a different season to avoid season-associated variation as well as to insure the greatest diversity of fungi where obtained. A total of 22 Myrtaceae species native to Uruguay and 12 species of Eucalyptus were examined (Table 1). Only 22 out of 35 native Myrtaceae species were found on the sampled sites, the others were either not geographically located in the regions where Eucalyptus was planted or if present, they were in very low frequency and not found during the surveys.

Samples of infected leaves were collected in plastic bags, and transported in a cooler at $8^{\circ} \mathrm{C}$ to the laboratory. Each rust sample was divided in the laboratory, where a small amount of leaf tissue bearing pustules was dried in small paper envelopes for later analysis. Urediniospores were collected from fresh pustules and stored at $-80^{\circ} \mathrm{C}$ in glass capsules until they could be used in pathogenicity tests.

Table 1. List of native and non-native Myrtaceae that were sampled and provinces where each host species was examined. 


\begin{tabular}{|c|c|c|c|}
\hline $\begin{array}{l}\text { Myrtaceae spocies } \\
\text { native to Unuguay }\end{array}$ & Provinces where each host was examined & $\begin{array}{l}\text { Cultivated } \\
\text { Myrtaceae }\end{array}$ & Provinces where each host was examined \\
\hline Acca sellowiana & Rivera, Tacuarembo, Lavalkej, Treinta y Tres & Eucalyptus bicostata & Rio Negro \\
\hline Agariota etcalypades & Rivera & Eucalyphus camaldalensis & $\begin{array}{l}\text { Durazno, Paysandú, Rio Negro, Treinta y } \\
\text { Tres }\end{array}$ \\
\hline Blepharocalyx salkifolius & $\begin{array}{l}\text { Durazno, Florida, Lavalleja, Maldonado, Paysandú, } \\
\text { Rio Negro, Rivera, Tacuaremb6, Treinta y Tres }\end{array}$ & Eucalyptus cinerea & Paysandú, Tacuarembo \\
\hline Calyptranthes concinna & Rivera, Treinta y Tres & Eucalyptus dunnii & $\begin{array}{l}\text { Durazno, Florida, Paysandú, Río Negro, } \\
\text { Tacuarembo }\end{array}$ \\
\hline Eugenia invokicrata & Tacuaremb 6 & Eucalyptus ficifolia & Paysandú \\
\hline Eugenia mansonii & Durazno, Rivera, Tacuarembó & Eucalyptus globulus & $\begin{array}{l}\text { Canelones, Duramo, Florida, Lavalleją, } \\
\text { Maldonado, Paysandú, Rio Negro, } \\
\text { Tacuar embó }\end{array}$ \\
\hline Eugenia repanda & Lavalleja, Rio Negro, Treinta y Tres & Eucalyptus grand is & $\begin{array}{l}\text { Duranno, Paysandú, Rio Negro, Rivera, } \\
\text { Tacuarembs }\end{array}$ \\
\hline Eugenia taniflora & $\begin{array}{l}\text { Durazno, Florida, Tacuaremb } \delta \text {, Treinta y Tres, } \\
\text { Rivera }\end{array}$ & Etucalyptus maidenil & Durazno, Lavalleja, Paysandú, Rio Negro \\
\hline Eugenia uruguayensis & $\begin{array}{l}\text { Durazno, Paysandú, Rio Negro, Rivera, } \\
\text { Tacuarembó }\end{array}$ & Eucalyptus robusta & Tacuaremb 6 \\
\hline Gomidesia palustris & Rivera, Trienta y Tres & Eucalyptus saligna & Paysandú \\
\hline Hexachlamis eduäs & Paysandú, Río Negro & Eucalyptus tereficornis & $\begin{array}{l}\text { Durazno, Florida, Lavalleja, Paysandú, } \\
\text { Rio Negro, Rivera }\end{array}$ \\
\hline Myrceugenia euosma & Rivera, Tacuarembó & Eucalyptus viminalis & Lavalleja \\
\hline Myrceugenia giaucescens & $\begin{array}{c}\text { Duramo, Lavalleja, Maldonado, Paysan dú, Rio } \\
\text { Negro, Rivera, Tacuarembo, Treinta y Tres }\end{array}$ & Syzygiam jambos & Canelones \\
\hline Myrcianthes cisplatensis & $\begin{array}{l}\text { Duramo, Maldonado, Paysandú, Río Negro, } \\
\text { Rivera, Tacuaremb } \delta \text {, Treinta y Tres }\end{array}$ & & \\
\hline Myrcianthes gigantea & Treinta y Tres & & \\
\hline Myrcianthes pungens & Paysan dú, Rivera, Tacuaremb $\delta$, Treinta y Tres & & \\
\hline Myrciaria tene IIa & Lavalleja, Maldonado, Rivera & & \\
\hline $\begin{array}{l}\text { Myrrhinium atropurpureum } \\
\text { var. octandrum } \\
\text { Psitium cattleianam }\end{array}$ & $\begin{array}{l}\text { Duramo, Lavalleja, Maldonado, Paysandú, } \\
\text { Rivera, Tacuaremb } \delta \\
\text { Treinta y Tres }\end{array}$ & & \\
\hline Psifium haridum & Rivera & & \\
\hline Psitium incantom & Rivera & & \\
\hline Psitium pubifolitam & Paysan dú, Rivera & & \\
\hline
\end{tabular}

Those spocies on which nust infoctions were observed are in bold

\section{Rust morphology}

Teliospores and urediniospores were compared using standard light microscope techniques. Teliospores were germinated on a slide with free water for $180 \mathrm{~min}$ and observed under the microscope to examine promycelia and cell number. In addition, urediniospore morphology was observed using a Hitachi S-3500 N Variable Pressure Scanning Electron Microscope (SEM) at the Imaging Center, College of Biological Science, University of Minnesota. For each sample, spores were attached to stubs with a thin layer of adhesive. Stubs were coated with gold and placed in the low-vacuum, variable pressure Environmental SEM and photographed with a digital camera at approximately $\times 2,000$ magnification.

\section{DNA extraction, PCR, sequencing and phylogenetic analysis}

DNA was extracted from dried infected host leaf tissue $(\sim 20 \mathrm{mg})$ containing uredinial pustules. Dried host tissue with spores was shaken in tubes with sterile 1-mm glass beads (Lysing matrix C; Bio 101, Carlsbad, CA, USA) and $25 \mathrm{mg}$ of sterile diatomaceous earth (Sigma-Aldrich, St. Louis, MO, USA) in a Savant FastPrep shaker (FP120; Holbrook, NY, USA) for $20 \mathrm{~s}$ at a speed setting of 5 (Zambino 2002). DNA extraction was performed using OmniPrepTM DNA Extraction Kit (Biosciences, Saint Louis, MO) following the manufacturer's instructions. 
The internal transcribed spacer region of the ribosomal DNA (ITS) was amplified using primers ITS-1F (5' CTT GGT CAT TTA GAG GAA GTA A 3') and ITS-RUST1 (5' GCT TAC TGC CTT CCT CAA TC 3') (Kroop et al. 1995). Primers PR1 (5' AAA TCG TAA CAA GGT TTC CG 3') and PR2 (5' TAA GTT CAG CAG GTA GTC CC 3') (Langrell et al. 2008) were used for those samples for which no PCR product was obtained with the former pair of primers. Polymerase Chain Reaction (PCR) was performed in a $50-\mu 1$ reaction mixture of $5.0 \mu 1$ of $0.05 \%$ casein, $5.0 \mu 1$ of $10 \mathrm{X}$ PCR Buffer, $1.5 \mu \mathrm{l}$ of $50 \mathrm{mM} \mathrm{MgCl}, 1.0 \mu \mathrm{l}$ of $10 \mathrm{mM}$ dNTPs, $1.0 \mu \mathrm{l}$ of $20 \mathrm{mM}$ ITS-1F, $1.0 \mu \mathrm{l}$ of 20 mM ITS-RUST1, $0.2 \mu \mathrm{l}$ of Platinum Taq Polymerase, $30.3 \mu \mathrm{l}$ of $\mathrm{ddH}_{2} \mathrm{O}, 5.0 \mu \mathrm{l}$ of DNA template. PCR amplifications were performed in a MJ Research PTC 200 DNA Engine Thermal Cycler PCR (MJ Research, Reno, NV) with the following parameters: an initial denaturation step of 2 min at $94^{\circ} \mathrm{C}$, followed by 30 cycles of $30 \mathrm{sec}$ at $94^{\circ} \mathrm{C}, 30 \mathrm{sec}$ at $44^{\circ} \mathrm{C}, 2 \mathrm{~min}$ at $72^{\circ} \mathrm{C}$ and final extension of $10 \mathrm{~min}$ at $72^{\circ} \mathrm{C}$; hold at $4^{\circ} \mathrm{C}$.

PCR products were visualized by $1.5 \%$ agarose gel electrophoresis, purified and prepared for sequencing using EXO-SAP-IT PCR clean-up kit (USB, Cleveland, OH, USA) following the manufacturer's instructions. Sequencing reactions were performed using the same primers as those for the PCR and the ABI Prism Big Dye Terminator Cycle Sequencing Ready Reaction Kit (Applied Biosystems, Forest City, CA, USA) on an ABI Prism 377 automated DNA sequencer. Sequences were obtained in both directions and assembled using ChromasPro software (Technelysium, Eden Prairie, MN, USA). Assembled sequences were subject to BLAST searches in the NCBI GenBank. Phylogenetic analysis was performed to confirm species identification. Thus, Puccinia psidii sequences available in GenBank were downloaded along with sequences of the rust species that showed the closest match with $P$. psidii. Following a preliminary phylogenetic analysis, the alignment was trimmed leaving only representative species of closest related taxa (Table 3). Phakopsora pachyrhizi was chosen as the outgroup taxon. Multiple sequence alignments were made online using the E-INS-i strategy in MAFFT version 6 (Katoh et al. 2005).

Phylogenetic analysis was performed using PAUP Version 4.0b10 (Swofford 2002) for maximum parsimony analysis and Mr. Bayes v3.1.2 (Ronquist and Huelsenbeck 2003) for Bayesian analysis. Maximum parsimony analysis was performed using the heuristic search option with simple taxa additions and tree bisection and reconnection (TBR) as the branch-swapping algorithm. Support for the nodes of the shortest trees was determined by analysis of 1,000 bootstrap replicas (Hillis and Bull 1993). Tree length (TL), consistency index (CI), retention index (RI), and homoplasy index (HI) were calculated.

The best nucleotide substitution model for the Bayesian analysis was determined using MrModeltest v2.2 (Nylander 2004). The general time reversible substitution model including a proportion of invariant sites and gamma-distributed substitution rates of the remaining sites (GTR + $\mathrm{I}+\mathrm{G})$ was selected using AIC. Two independent runs each using four MCMC chains starting from a random tree topology were run over 10 million generations. Trees were sampled every 100th generation and the "burnin" was set at 6,000 generations after which the likelihood values were stationary. To obtain the estimates for the posterior probabilities, a 50\% majority rule consensus of the remaining 99,941 trees was computed from a total of 199,882 sampled trees. Bayesian analysis was repeated three times, showing identical tree topology, indicating that topology was independent from priors. Results for one out of the three replicates were randomly selected for presentation.

\section{Pathogenicity tests}

To assess pathogenicity of the rust samples collected on native Myrtaceae trees to Eucalyptus, E. globulus and E. grandis seedlings were inoculated with a suspension of urediniospores from each of the two rust collections (UY 220 and UY221) under controlled conditions. Three clones of $E$. globulus (A, B and C) and three clones of E. grandis (D, E and F) were inoculated with each rust 
sample, using the urediniospores that were collected from fresh pustules and that had been stored at $-80^{\circ} \mathrm{C}$. In addition to Eucalyptus, Syzygium jambos (L.) Alston plants were inoculated, since this tree species has been shown to be highly susceptible to $P$. psidii and it is frequently used for inoculum preservation and multiplication (Junghans et al. 2003).

One 4-month-old seedling of each host was inoculated with each rust sample. Inoculation was conducted using a pipette to apply five drops of suspension per leaf on five leaves per plant. Each drop was approx. $20 \mu \mathrm{l}$ of a spore suspension with $5 \times 104$ urediniospores $/ \mathrm{ml}$. Inoculated plants were incubated $24 \mathrm{~h}$ in a mist chamber at $25^{\circ} \mathrm{C}$ in the dark and then transferred to a growth chamber at $22^{\circ} \mathrm{C}$ with $12-\mathrm{h}$ photoperiod, at $40 \mu \mathrm{mol}$ photons $/ \mathrm{s} / \mathrm{m}^{2}$ of light intensity. Twelve days later, plants were evaluated for the presence of rust pustules. Those plants showing negative results (i.e., no pustules) were evaluated again 21 days post-inoculation to confirm the absence of pustules. DNA was extracted from urediniospores present on pustules from inoculated plants, sequenced as described above, and compared with the inoculated specimen-sequence to confirm its identity. Pathogenicity tests were replicated once.

\section{Results}

\section{Samples collected}

Rust on native trees was very rare and after examining several trees of native Myrtaceae species during 2 years of surveys, this rust was found only on Myrrhinium atropurpureum Schott var. octandrum Benth and Myrcianthes pungens (Berg) Legrand. Rust pustules were also observed on Eucalyptus globulus and Eucalyptus grandis plantations. All diseased Eucalyptus trees were 1 year old, whereas the native trees with disease symptoms were adult specimens of unknown age. Rust infections were also observed on E. globulus and E. grandis cuttings in two nurseries located in Paysandú and Canelones, respectively. One sample collected on S. jambos from a nursery in Canelones was also included in this study (Table 2).

Table 2. Host, location and date of collection of specimens analyzed in this study.

\begin{tabular}{|c|c|c|c|c|}
\hline Rust ID & Host & Location & Age of the host & Date of colloction \\
\hline UY217 & Eucalyptus grandis & Tacuarembó, $31^{\circ} 41^{\prime} \mathrm{S}, 55^{\circ} 57^{\prime} \mathrm{W}$ & Re-growth, 1 year old & $11 / 18 / 05$ \\
\hline UY220 & Myrrhinium atropurpureum var. actandrum & Tacuarembó, $31^{\circ} 35^{\prime} \mathrm{S}, 55^{\circ} 47^{\prime} \mathrm{W}$ & Adult trœ & $11 / 18 / 05$ \\
\hline UY221 & Myrcianthes pungens & Tacuarembó, $31^{\circ} 33^{\prime} \mathrm{S} 55^{\circ} 43^{\prime} \mathrm{W}$ & Adult tree & $11 / 18 / 05$ \\
\hline UY894 & E. globulus & Lavalleja, $34^{\circ} 20^{\prime} \mathrm{S}, 55^{\circ} 09^{\prime} \mathrm{W}$ & 1 year old & $05 / 11 / 06$ \\
\hline UY895 & E. globulus & Maldonado, $34^{\circ} 19^{\prime} \mathrm{S}, 54^{\circ} 44^{\prime} \mathrm{W}$ & 1 year old & $04 / 05 / 06$ \\
\hline UY 1371 & E. grandis & Paysandú, $32^{\circ} 15^{\prime} \mathrm{S}, 58^{\circ} 05^{\prime} \mathrm{W}$ & 4 months old cutting in a nursery & $01 / 16 / 07$ \\
\hline UY 1372 & E. grandis & Rio Negro, $32^{\circ} 25^{\prime} \mathrm{S}, 57^{\circ} 22^{\prime} \mathrm{W}$ & 2 years old & $01 / 22 / 07$ \\
\hline UY 1374 & E. globulus & Canelones, $34^{\circ} 40^{\prime} \mathrm{S}, 56^{\circ} 20^{\prime} \mathrm{W}$ & 4 months old cutting in a nursery & $01 / 30 / 07$ \\
\hline UY 1375 & E. globulus & Canelones, $34^{\circ} 40^{\prime} \mathrm{S}, 56^{\circ} 20^{\prime} \mathrm{W}$ & 4 months old cutting in a nursery & $01 / 30 / 07$ \\
\hline UY1731 & E. grandis & Canelones, $34^{\circ} 40^{\prime} \mathrm{S}, 56^{\circ} 20^{\prime} \mathrm{W}$ & 4 months old cutting in a nursery & $12 / 04 / 07$ \\
\hline UY 1732 & Syzygùum jambos & Canelones, $34^{\circ} 40^{\prime} \mathrm{S}, 56^{\circ} 20^{\prime} \mathrm{W}$ & 1 year old cutting in a nursery & $12 / 04 / 07$ \\
\hline
\end{tabular}

\section{Symptoms and morphology}

Similar symptoms were observed on different hosts infected with P. psidii. Lesions were primarily observed on young tissues such as actively growing leaves and shoots (Fig. 1). Bright orange pustules with orange-yellow urediniospores were present on all evaluated hosts, but dark orangebrown teliospores were observed only on E. globulus and E. grandis. Gray discoloration of old lesions was observed on E. grandis, and shoot tips were dead on E. grandis and M. atropurpureum var. octandrum (Fig. 1). Teliospores were similar to those reported by Walker (1983), roughly ellipsoidal to cylindrical to broadly clavate, one-septate, constricted at the central septum, 26-42 $\times$ 
15-22 $\mu \mathrm{m}$, with the upper cell generally slightly wider and shorter than the lower, wall pale golden yellow, pore apical in the upper cell and just below the septum in the lower cell, pedicels either deciduous or short (up to $15 \mu \mathrm{m}$ long). However, in sample UY895 teliospores had pedicels of up to $25 \mu \mathrm{m}$ long (Fig. 2a). Germinated teliospores produced a four-celled basidium with four basidiospores (Fig. 2b).
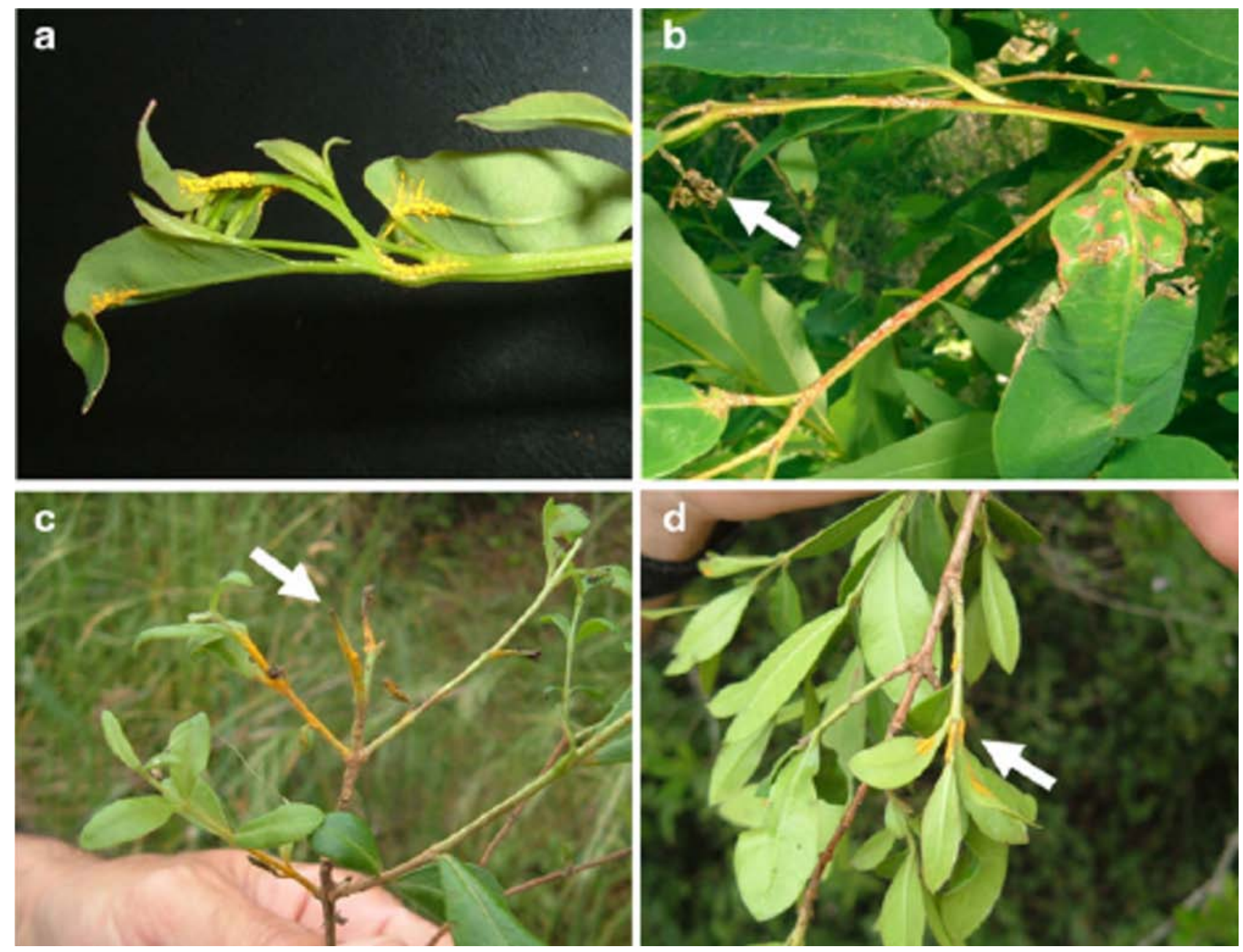

Figure 1. Symptoms of Eucalyptus rust on different hosts. a Young lesions on E. grandis, the pustules are bright orange on young tissue. b Old lesions on E. grandis, grey discoloration on leaves and twigs and dead shoot tip. c,d Pustules on twigs, leaves and petioles of Myrrhinium atropurpureum var. octandrum appear bright orange. Trees also have dead shoot tips. Arrows show areas of dying shoot tips and location of orange urediniospores on infected branches.

Urediniospores examined from each specimen showed a high level of similarity in spore size, spine density and spine distribution on the spore surface. Urediniospores were observed in all collected samples. They were of 19-26 x 15-22 $\mu \mathrm{m}$, yellow, unicellular, spherical to elliptical, base truncate, finely and uniformly echinulate with spines up to $1 \mu \mathrm{m}$ long, $0.5-1.5 \mu \mathrm{m}$ apart. In some urediniospores, a bald patch without spines was observed (Fig. 2c-f).

\section{Phylogenetic analysis}

DNA fragments of approximately $640 \mathrm{bp}$ were amplified for all specimens. Sequences were deposited in GenBank and accession numbers are shown in Table 3. The ITS dataset consisted of 34 ingroup sequences plus Phakopsora pachirhizi used as the outgroup taxon. Aligned DNA sequences of 596 total characters included the complete ITS region (ITS1, 5.8 S and ITS2 regions), of which 245 were constant, 53 variable characters were parsimony-uninformative and 298 were parsimony informative. Maximum parsimony and Bayesian analyses resulted in trees of identical topology. 
The heuristic search analysis of the data resulted in 2 most parsimonious trees ( $\mathrm{TL}=733$ steps; $\mathrm{CI}=$ $0.748 ; \mathrm{RI}=0.910 ; \mathrm{HI}=0.252$ ). The phylogram obtained from the Bayesian analysis is shown in Fig. 3. The aligned sequence data were deposited in TreeBASE (ID 10699).
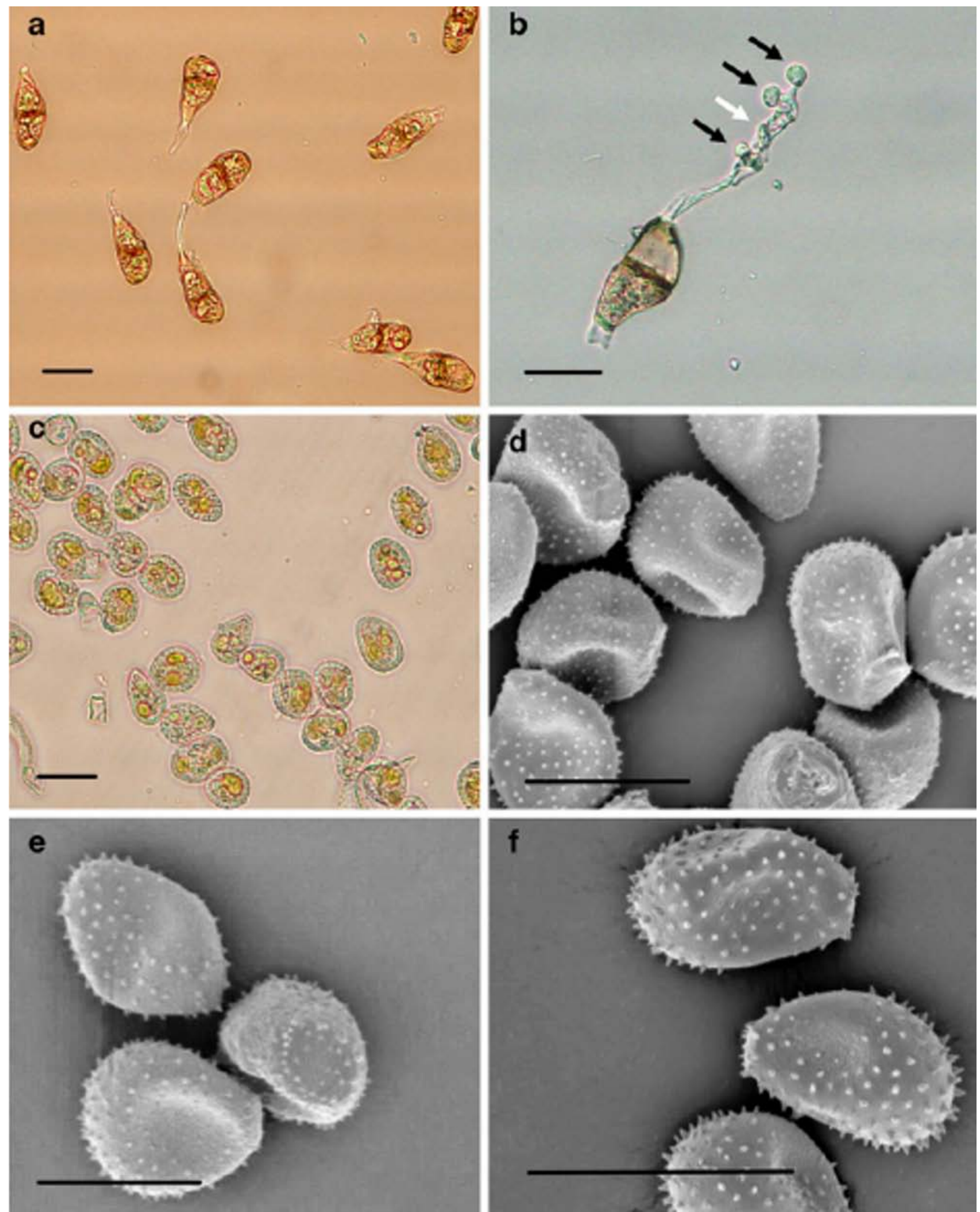

Figure 2. a-c Light micrographs of teliospores and urediniospores of $P$. psidii. a Teliospores observed in sample UY895 with most characteristics as previously described by Walker (1983). However, some spores display a pedicel up to $25 \mu \mathrm{m}$ long. b Germinated teliospore. Black arrows indicate each basidiospore and the white arrow indicates the location where the fourth basidiospore had been ejected. c Urediniospores from sample UY217. d-f Scanning electron micrographs of 
gold-coated urediniospores of P. psidii collected on d E. grandis (UY217), e Myrrhinium atropurpureum var. octandrum (UY220), and f Myrcianthes pungens (221). Bars $20 \mu \mathrm{m}$

Table 3. List of sequences used in this study, including those for which sequences were obtained from GenBank.

\begin{tabular}{|c|c|c|c|c|c|}
\hline $\begin{array}{l}\text { Collection } \\
\text { ID no. }\end{array}$ & Rust & Host spœies & Location ${ }^{a}$ & $\begin{array}{l}\text { GenBank } \\
\text { accession no. }\end{array}$ & Reference \\
\hline UY $217^{b}$ & Puccinia psidii & Eucalyptus grandis & Tacuarembó, Uruguay & EU348742 & This study \\
\hline UY220 & P. psidii & $\begin{array}{l}\text { Myrrhinium atropurpureum } \\
\text { var. octandrum }\end{array}$ & Tacuarembó, Uruguay & EU439920 & This study \\
\hline UY221 & P. psidii & Myrcianthes pungens & Tacuarembó, Uruguay & EU439921 & This study \\
\hline UY 894 & P. psidii & Euc globuhts & Maldonado, Uruguay & EU348743 & This study \\
\hline UY1371 & P. psidii & Euc grandis & Paysandú, Unuguay & FJ710803 & This study \\
\hline UY1372 & P. psidii & Euc grandis & Río Negro, Uruguay & FJ710804 & This study \\
\hline UY 1374 & P. psidii & Euc globuhts & Canelones, Uruguay & FJ710805 & This study \\
\hline UY1731 & P. psidii & Euc. grandis & Canelones, Uruguay & FJ710807 & This study \\
\hline UY1732 & P. psidii & Syzygium jambos & Canelones, Uruguay & FJ710808 & This study \\
\hline E-UFV8 & P. psidii & Euc. grandis & Espirito Santo, Brazil & AJ 535660 & Langrell et al. 2008 \\
\hline MG27 & P. psidii & Eugenia uniflora & Minas Gerais, Brazil & AJ421 801 & Langrell et al. 2008 \\
\hline MG32 & P. psidii & Melalenca quinquinervia & Minas Gerais, Brazil & AJ421 802 & Langrell et al. 2008 \\
\hline USA2 & P. psidii & Mel. quinquinerva & Florida, USA & AJ 535658 & Langrell et al. 2008 \\
\hline SZ2.18 & P. psidii & Mel. quinquinenvia & Hawaii, USA & EU071045 & Langrell et al. 2008 \\
\hline n'a & P. psidii & Metrosideros polymorpha & Hawaii, USA & EF599768 & Uchida et al., 2006 \\
\hline MG63 & P. psidii & Myrcia jaboticaba & Minas Gerais, Brazil & AJ421 805 & Langrell et al. 2008 \\
\hline USA 3 & P. psidii & Pimenta diaca & Florida, USA & AJ535659 & Langrell et al. 2008 \\
\hline $\mathrm{SCl}$ & P. psidii & Psidium guajava & Santa Catarina, Brazil & AJ 536601 & Langrell et al. 2008 \\
\hline UFV18 & P. psidii & S. jambos & Minas Gerais, Brazil & AJ421 800 & Langrell et al. 2008 \\
\hline USAI & P. psidii & S. jambos & Florida, USA & AJ 535657 & Langrell et al. 2008 \\
\hline HSZ0219 & P. andropogonis & $\mathrm{n} / \mathrm{a}$ & - & DQ344517 & Szabo 2006 \\
\hline HSZ0027 & P. andropogonis & $\mathrm{n} / \mathrm{a}$ & - & DQ344518 & Szabo 2006 \\
\hline HSZ0928 & P. graminis f.sp. dactyis & Dactylis glomerata & - & DQ417390 & Barnes and Szabo 2007 \\
\hline HSZ0929 & P. grantinis $\mathrm{f} . s p$ poae & Poa pratensis & - & DQ417389 & Barnes and Szabo 2007 \\
\hline IBA8759 & P. hemerocalidis & $\mathrm{n} / \mathrm{a}$ & - & $\mathrm{AB} 232547$ & Chatasiri et al. 2006 \\
\hline IBA 8749 & P. hemerocallidis & $\mathrm{n} / \mathrm{a}$ & - & $\mathrm{AB} 232546$ & Chatasiri et al. 2006 \\
\hline $\mathrm{CDL} 22 / 81$ & P. horda & $\mathrm{n} / \mathrm{a}$ & - & AY511086 & Anikster et al. 2004 \\
\hline CDL64-2B & P. horde & $\mathrm{n} / \mathrm{a}$ & - & AY1 87089 & Anikster et al. 2004 \\
\hline $11506 \mathrm{~F}$ & P. recondita & $\mathrm{n} / \mathrm{a}$ & - & AY956553 & Abbasi et al. 2004 \\
\hline ANK 77081 & P. recondita & Tritioum turgidum & - & AF511082 & Barnes and Szabo 2007 \\
\hline HSZ0711 & P. striiformis f. $\mathrm{sp}$ hordei & Hondenem vulgare & - & DQ417402 & Barnes and Szabo 2007 \\
\hline PSH13 & P. striiformis f. sp. hordei & Hor. vulgare & - & DQ417408 & Barnes and Szabo 2007 \\
\hline HSZ0741 & P. triticina & T. aestivim & - & DQ417409 & Barnes and Szabo 2007 \\
\hline HSZ0741 & P. triticina & T. aestivim & & DQ417411 & Barnes and Szabo 2007 \\
\hline Brazil-1 & Phakopsora pachyrhizi & Glycine max & - & EU523736 & Silva ct al. 2008 \\
\hline
\end{tabular}

${ }^{2}$ Location only indicated for $P$. psifit collections

${ }^{b}$ Specimens sequenced in this study are shown in bold

Phylogenetic analysis showed a high level of similarity among the nine samples and they grouped together with ITS sequences of $P$. psidii obtained from GenBank while also clearly separated from the most closely related species for which sequences have been published. Minor variation in the analyzed ITS regions was observed among the sequences of the six samples collected on Eucalyptus spp. and the one collected on S. jambos. The only change observed was in the sequence UY1372, which showed ambiguity at the position 396 of the alignment with a double peak of guanine and adenosine. In contrast, the two samples collected on the native myrtaceous trees displayed most variation ( 5 changes) in the ITS2 region. The sequence of UY220 collected from Myrrhinium atropurpureum var. octandrum showed an insertion of a guanine in the position 311 of the alignment, and substitutions of guanine instead of adenosine in two different positions 


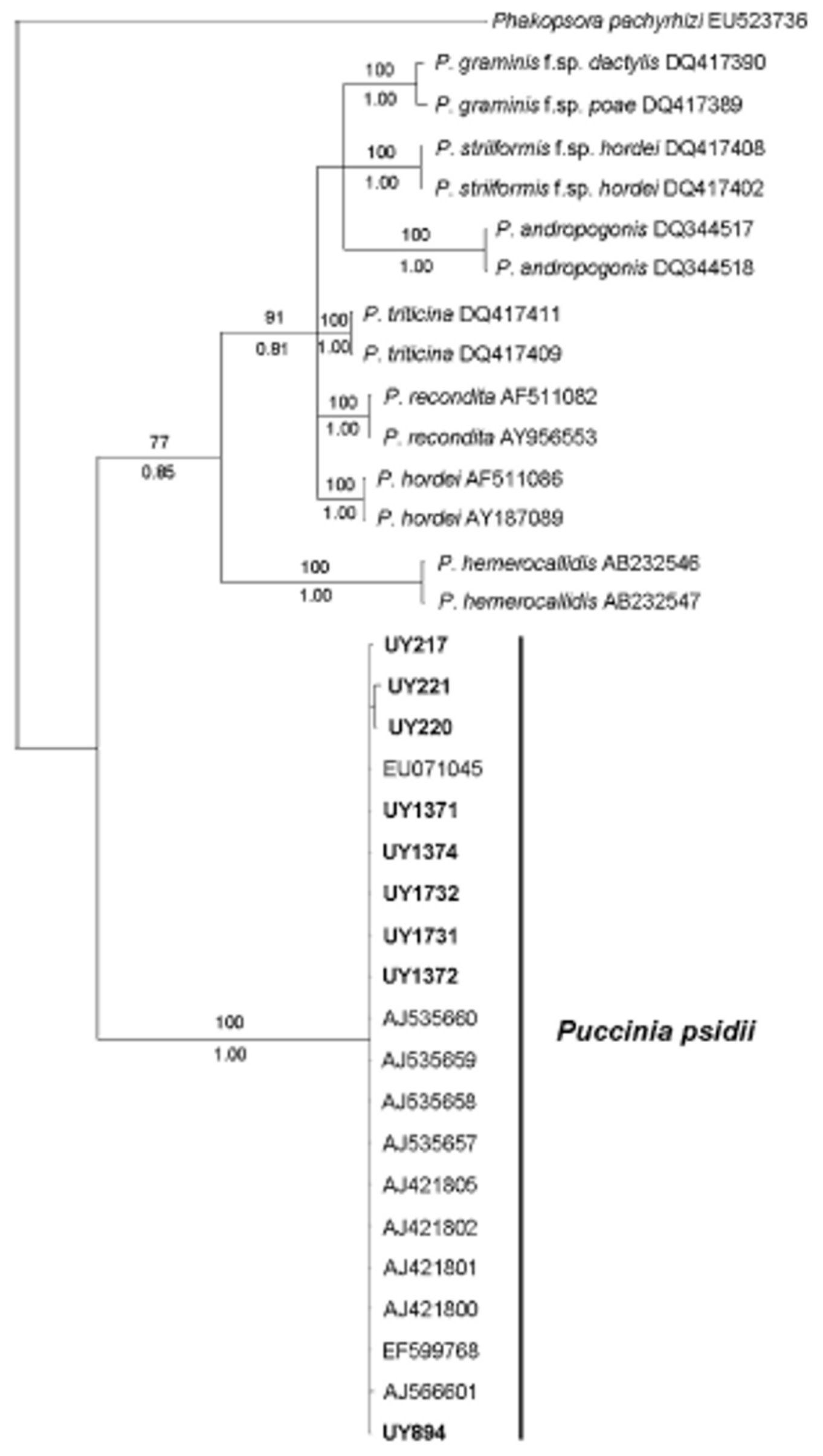


Figure 3. Phylogram obtained from the Bayesian analysis based on the ITS region indicates the phylogenetic relationship among rust sequences obtained from rust on Eucalyptus and native Myrtaceae trees in Uruguay (labeled UY and in bold), P. psidii and other related rusts. Bootstrap values of 1,000 replicates of maximum parsimony $(>75 \%)$ and posteriori probabilities are shown below and above branches, respectively. The tree was rooted to Phakopsora pachyrhizi.

(i.e. position 396 and 453, respectively). On the other hand, DNA sequence of UY221 from Myrcianthes pungens showed the same substitution in the position 396 plus insertions of one adenosine and one thiamine at the positions 503 and 530, respectively.

\section{Pathogenicity tests}

The two rust samples collected from native Myrtaceae (UY220 and UY 221) that were used in the pathogenicity tests were able to infect and produce new uredinial pustules on the different clones of E. globulus. However, UY220 was able to sporulate only on E. grandis clones D and F, and no infection was observed on E. grandis clone E. Syzygium jambos showed no signs of infection by either rust isolate used in the inoculations (Table 4).

Table 4. Results of pathogenicity tests performed on three clones of E. globulus and E. grandis as well as S. jambos inoculated with the two rust samples collected from native Myrtaceae trees (UY220 and UY221).

\section{Eucalyptus globulus Eucalyptus grandis Syzygium jambos}

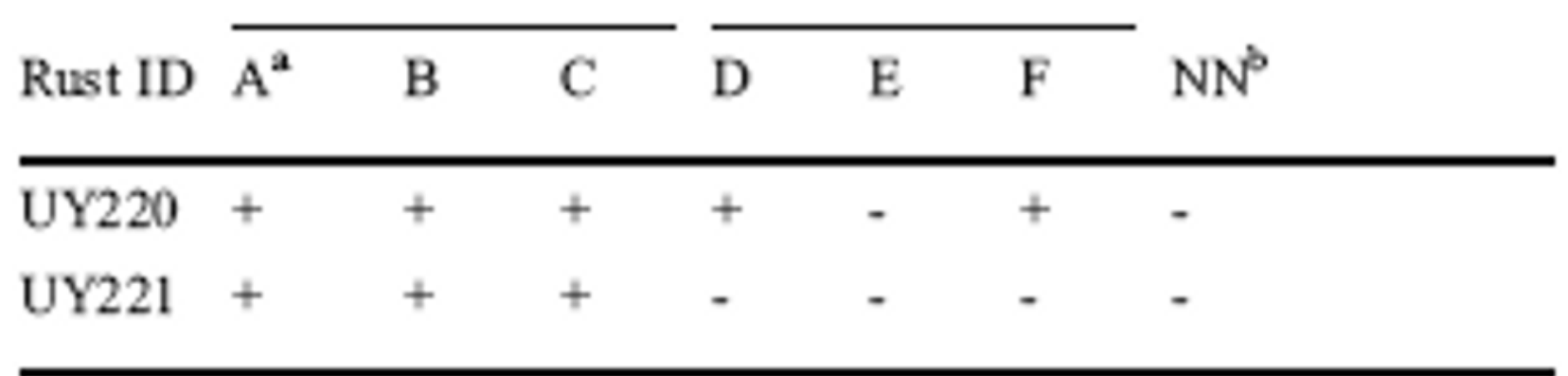

+ and - indicate presence/absence of pustules 12 days post-inoculation

${ }^{a}$ code of the clone

\section{${ }^{\mathrm{D}} \mathrm{NN}$ No name}

Although severity of infection was not specifically assessed, clear differences in number and size of pustules were observed between rust samples on different clones of E. globulus, clone A was just slightly infected by both rust samples, clone $\mathrm{C}$ was more severely infected by UY220 but slightly infected by UY221 and clone B was slightly infected by UY220 and moderately infected by UY221.

\section{Discussion}

This study has led to the discovery of two previously unknown native Myrtaceae hosts of $P$. psidii in Uruguay. They further provide conclusive evidence based on DNA sequence comparisons that the rust fungus occurs on native Myrtaceae in the country and that it is the same fungus that is found on non-native Eucalyptus spp. in plantations. DNA-based evidence for these findings is supported by morphological characteristics of the fungus. The results have also shown, for the first 
time, that rust isolates from native trees can infect Eucalyptus spp. in Uruguay.

Previously, $P$. psidii in Uruguay has been reported on Psidium brasiliensis (Koch de Brotos et al. 1981) and Eucalyptus globulus (Balmelli et al. 2004; Telechea et al. 2003). In this study, we found the fungus on Eucalyptus globulus, E. grandis, Myrcianthes pungens, and Myrrhinium atropurpureum var. octandrum although infections were not abundant. Finding P. psidii on native trees and the scarcity of infections observed support the view that the fungus is native in Uruguay. If so, it would be under strong ecological homeostasis. Uruguay has 35 native species of Myrtaceae (Brussa and Grela 2007) and we expect that many of these trees could be hosts to this rust with its unusually broad host range (Simpson et al. 2006). It has undergone significant host shifts to nonnative trees such as Eucalyptus (Coutinho et al. 1998; Slippers et al. 2005) and Metrosideros (Uchida et al. 2006). Confirmed by morphological characteristics and phylogenetic comparisons, this is the first report of $P$. psidii on $M$. atropurpureum var. octandrum and the first report of $P$. psidii on these two native hosts in Uruguay, although it has been previously reported on $M$. pungens in Brazil (Hennen et al. 2005).

Symptoms on both Eucalyptus spp. and native Myrtaceae trees were consistent with those described previously (Alfenas et al. 2004; Old et al. 2003). The profuse production of teliospores observed in this study under field conditions suggests that $P$. psidii is a heteroecious macrocyclic rust for which the alternate aecial host is unknown. This view was also proposed by Simpson et al. (2006). However, it is possible that $P$. psidii is apomictic, since aecia and aeciospores have been observed after inoculations with basidiospores on Eucalyptus and Syzygium jambos (Ferreira 1989; Figueiredo et al. 1984).

Even though we did not examine the number of nuclei present in each basidiospore produced from germinated teliospores, four basidiospores were produced from each teliospore and we expect that these would give rise to monokaryotic basidiospores. Alfenas et al. (2004) made a similar observation, and it raises a question about when it undergoes dikaryotization. Pycnia have never been observed in P. psidii and the stage where dikaryon formation takes place has yet to be discovered.

Results of this study provide strong preliminary evidence that $P$. psidii is genetically diverse in Uruguay. Although the sample size was relatively small, DNA sequence data showed that isolates are genetically different. Furthermore, pathogenicity tests with different $P$. psidii isolates also suggested differences in the susceptibility of Eucalyptus hosts. Further studies will be needed to determine whether this represents intraspecific variation in the ITS region or whether $P$ psidii, comprises several cryptic species. Genetic variation based on much larger collections of isolates should be undertaken to better understand the population genetics of this pathogen and thus differences in resistance and susceptibility that were observed in Eucalyptus clones.

An interesting observation in this study was that Syzygium jambos was not infected in pathogenicity tests. This tree is one of the hosts most susceptible to $P$. psidii elsewhere in the world (Junghans et al. 2003). Physiological variability is known in $P$. psidii and characterization of different physiological groups (or biotypes) based on cross-inoculations have been described previously (Aparecido et al. 2003; Coelho et al. 2001; De Castro et al. 1983). Lack of susceptibility to isolates of $P$. psidii in $S$. jambos emphasizes the fact that the pathogen is physiologically variable in Uruguay and that it is most likely native to the area in which it was discovered in this study. This is likely to complicate Eucalyptus forestry in Uruguay and it will mean that screening of clones will need to include the breadth of variability of the rust. It will also be important to understand the population structure of the rust to allow the development of effective breeding programs that will minimize the economic impact of $P$. psidii in Uruguay. 


\section{Acknowledgements}

We acknowledge the financial and logistic support of Forestal Oriental, Rivermol, Stora Enso and Weyerhaeuser Uruguay, as well as Eufores and Forestal Oriental for supplying clones for inoculation. We also thank Andrés Berrutti, Brett Arenz, Charles Barnes, Gustavo Balmelli, Jason Smith, Kim Nguyen and Les Szabo for their assistance and discussions on various aspects of these investigations.

\section{References}

Abbasi M, Hedjaroude G, Scholler M, Goodwin SB (2004) Taxonomy of Puccinia striiformis s.1. in Iran. Rustaniha 5:199-224

Acuña M, Garran SM (2004) Detección de Kirramyces epicoccoides, Puccinia psidii y Coniothyrium zuluense, agentes causales de enfermedades en Eucalyptus spp. en la zona de Concordia, Entre Ríos, Argentina. Revista INTA Argentina 33:135-148

Alfenas AC, Zauza EA, Mafia RG, Assis TF (2004) Clonagem e Doenças do Eucalipto. Universidade Federal do Viçosa, Brazil

Anikster Y, Szabo LJ, Eilam T, Manisterski J, Koike ST, Bushnell WR (2004) Morphology, life cycle biology, and DNA sequence analysis of rust fungi on garlic and chives from California. Phytopathology 94:569-577

Aparecido CC, Figueiredo MB, Furtado EL (2003) Grupos de variabilidade fisiológica em populações de Puccinia psidii. Summa Phytopathol 29:234-238

Balmelli G, Marroni V, Altier N, Garcia R (2004) Potencial del mejoramiento genético para el manejo de enfermedades en Eucalyptus globulus. INIA, Serie Técnica 143

Barnes CW, Szabo LJ (2007) Detection and identification of four common rust pathogens of cereals and grasses using real-time polymerase chain reaction. Phytopathology 97:717-727

Brussa CA, Grela IA (2007) Flora arbórea del Uruguay con énfasis en las especies de Rivera y Tacuarembo. COFUSA, Mosca, Uruguay

Chatasiri S, Kitade O, Ono Y (2006) Phylogenetic relationships among Puccinia hemerocallidis, $P$. funkiae, and P. patriniae (Uredinales) inferred from ITS sequence data. Mycoscience 47:123-129

Coelho L, Alfenas AC, Ferreira FA (2001) Physiologic variability of Puccinia psidii - the rust of Eucalyptus. Summa Phytopathol 27:295-300

Coutinho TA, Wingfield MJ, Alfenas AC, Crous PW (1998) Eucalyptus rust: a disease with the potential for serious international implications. Plant Dis 82:819-825

De Castro HA, Krugner TL, Ideriha CF, Cappello MS, Marchi AB (1983) Inoculação cruzada de Eucalyptus, goiaba (Psidium guajava) e jamboeiro (Syzygium jambos) com Puccinia psidii. Fitopatol Bras 8:491-497

Dianese JC, Moraes TS, Silva AR (1984) Response of Eucalyptus species to field infection by Puccinia psidii. Plant Dis 68:314-316 
Ferreira FA (1981) Ferrugem do eucalipto-ocurrência, temperatura para germinaçâo de uredosporos, produçâo de teliosporos, hospedeiro alternativo e resistencia. Fitopatol Bras 6:603-604

Ferreira FA (1983) Ferrugem do eucalipto. Revista Árvore 7:91-109

Ferreira FA (1989) Patología Forestal. Principais doenças florestais no Brazil. Sociedade de Investigaçòes Florestais, Brazil

Figueiredo MB, Coutinho LN, Hennen JF (1984) Estudos para determinação do ciclo vital de Puccinia psidii Winter. Summa Phytopathol 10:53-54

Glen M, Alfenas AC, Zauza EAV, Wingfield MJ, Mohammed C (2007) Puccinia psidii: a threat to the Australian environment and economy - a review. Australas Plant Pathol 36:1-16

Grgurinovic CA, Walsh D, Macbeth F (2006) Eucalyptus rust caused by Puccinia psidii and the threat it poses to Australia. EPPO Bulletin 36:486-489

Hennen JF, Figueiredo MB, de Carvalho AA, Hennen PG (2005) Catalogue of the species of plant rust fungi (Uredinales) of Brazil. Instituto de Pesquisas, Jardim Botânico do Rio de Janeiro, Brazil

Hillis DM, Bull JJ (1993) An empirical test of bootstrapping as a method for assessing confidence in phylogenetic analysis. Syst Biol 42:142-152

Joffily J (1944) Ferrugem do eucalipto. Bragantia 4:475-487

Junghans DT, Alfenas AC, Maffia LA (2003) Escala de notas para quantificação da ferrugem em Eucalyptus. Fitopatol Bras 28:184-188

Katoh K, Kuma K, Toh H, Miyata T (2005) MAFFT version 5: improvement in accuracy of multiple sequence alignment. Nucleic Acids Res 33:511-518

Kawanishi T, Uematsu S, Kakishima M, Kagiwada S, Hamamoto H, Horie H, Namba S (2009) First report of rust disease on ohia and the causal fungus, Puccinia psidii, in Japan. J Gen Plant Pathol $75: 428-431$

Koch de Brotos L, Boasso O, Riccio de Machado C, Gandolfo Antunez C (1981) Enfermedades de las plantas, hongos superiores y saprofitas en Uruguay. Departamento de Comunicaciones, Dirección de Sanidad Vegetal, Ministerio de Agricultura y Pesca, Uruguay

Kroop BR, Albee S, Flint KM, Zambino P, Szabo LJ, Thomson SV (1995) Early detection of systematic rust infections of Dyers Woad (Isatis tinctori L.) using polymerase chain reaction. Weed Sci 43:467-472

Langrell SRH, Glen M, Alfenas AC (2008) Molecular diagnosis of Puccinia psidii (guava rust) - a quarantine threat to Australian eucalypt and Myrtaceae biodiversity. Plant Pathol 57:687-701

MacLachlan JD (1938) A rust of the pimento tree in Jamaica. Phytopathology 28:157-170

Marlatt RB, Kimbrough JW (1979) Puccinia psidii on pimento dioica in South Florida. Plant Dis 63:510-512 
Nylander JA (2004) MrModeltest v2.2. Program distributed by the author. Evolutionary Biology Centre, Uppsala University, Sweden Old KM, Wingfield MJ, Yuan ZQ (2003) A manual of diseases of Eucalyptus in South-East Asia. Center for International Forestry Research, Jakarta, Indonesia

Rayachhetry MB, Van TK, Center TD, Elliott ML (2001) Host range of Puccinia psidii, a potential biological control agent of Melaleuca quinquenervia in Florida. Biol Control 22:38-45

Ronquist F, Huelsenbeck JP (2003) MrBayes3: Bayesian phylogenetic inference under mixed models. Biometrics 19:1572-1574

Silva DCG, Yamanaka N, Brogin RL, Arias CAA, Nepomuceno AL, Di Mauro AO, Pereira SS, Nogueira LM, Passianotto ALL, Abdelnoor RV (2008) Molecular mapping of two loci that confer resistance to Asian rust in soybean. Theor Appl Genet 117:53-63

Simpson JA, Thomas K, Grgurinovic CA (2006) Uredinales species pathogenic on species of Myrtaceae. Australas Plant Pathol 35:549-562

Slippers B, Stenlid J, Wingfield MJ (2005) Emerging pathogens: fungal host jumps following anthropogenic introduction. Trends Ecol Evol 20:420-421

Swofford DL (2002) PAUP*: phylogenetic analysis using parsimony (*and other methods). Version 4.0b10a. Sinauer Associates, Sunderland, Mass.

Szabo LJ (2006) Deciphering species complexes: Puccinia andropogonis and Puccinia coronata, examples of differing modes of speciation. Mycoscience 47:130-136

Telechea N, Rolfo M, Coutinho TA, Wingfield MJ (2003) Puccinia psidii on Eucalyptus globulus in Uruguay. Plant Pathol 52:427

Uchida J, Zhong S, Killgore E (2006) First report of a rust disease on 'Ohi'a caused by Puccinia psidii in Hawaii. Plant Dis 90:524

Walker J (1983) Pacific Mycogeography: deficiencies and irregularities in the distribution of plant parasitic fungi. Aust J Bot Suppl Ser 10:89-136

Winter G (1884) Repertorium. Rabenhorstii fungi europaei et extraeuraopaei. Cent. XXXI et XXXII. Hedwigia 23:164-172

Zambino EJ (2002) Dry grinding at near-ambient temperatures for extracting DNA from rust and other fungal spores. Biotechniques 33:48-51 